\title{
Species composition and richness of the herpetofauna of the semiarid environment of Nordestina, in northeastern Bahia, Brazil
}

\author{
André Kaufer Leite ${ }^{1,2 *}$ \\ Magno Lima Travassos de Oliveira ${ }^{1}$ \\ Marcelo Alves Dias 1,3 \\ Moacir Santos Tinôco ${ }^{1,2,3}$ \\ ${ }^{1}$ Centro de Ecologia e Conservação Animal, Universidade Católica do Salvador \\ Avenida Prof. Pinto de Aguiar, Pituaçu, CEP 41.740-090, Salvador - BA, Brazil \\ ${ }^{2}$ Laboratório de Estudos Herpetológicos e Paleoherpetológicos \\ Universidade Federal Rural de Pernambuco \\ Rua Dom Manuel de Medeiros, s/n, Dois Irmãos, CEP 52.171-900, Recife - PE, Brazil \\ ${ }^{3}$ Lacerta Consultoria, Projetos \& Assessoria Ambiental LTDA, Salvador - BA, Brazil \\ * Autor para correspondência \\ akleite@gmail.com
}

Submetido em 27/05/2019

Aceito para publicação em 14/10/2019

\section{Resumo}

Composição e riqueza da herpetofauna no semiárido do município de Nordestina, no Nordeste do estado de Bahia, Brasil. A herpetofauna da Caatinga continua subestimada. A falta de conhecimento levou essa região a ser considerada de baixa riqueza e endemismo. Este estudo tem como objetivo determinar a composição e riqueza de espécies da herpetofauna no município de Nordestina. Os dados foram coletados utilizando diferentes técnicas amostrais, como armadilha de interceptação e queda e procura ativa. A riqueza da herpetofauna foi estimada utilizando o estimador Bootstrap. Além disso, foram calculados também a dominância e equitabilidade por grupo taxonômico. No total, foram registrados 3.969 espécimes distribuídos em 49 espécies. As serpentes apresentaram maior riqueza, enquanto os lagartos foram mais abundantes. Para os anuros, estimou-se, aproximadamente, $14 \pm 0,8$ espécies, com alta uniformidade (índice de Pielou J' $=65,8 \%$ ) e baixa dominância $(\mathrm{D}=23,3 \%)$, enquanto que, para os répteis, o valor de riqueza estimado foi o mesmo observado, também com alta uniformidade $\left(\mathrm{J}^{\prime}=55,7 \%\right)$ e baixa dominância $(\mathrm{D}=23,9 \%)$. No geral, a área apresenta um padrão de equitabilidade e baixa dominância, o que é uma característica dos ambientes mais conservados e nos leva a destacar a importância desta região para a manutenção da biodiversidade do bioma Caatinga.

Palavras-chave: Anfíbios; Áreas prioritárias; Caatinga; Conservação; Répteis

\section{Abstract}

The herpetofauna of the Caatinga is still underestimated. A lack of knowledge of this group led the region to be perceived as having low species richness and endemism. This study aims to determine the species composition of the herpetofauna of the municipality of Nordestina. Data were collected using different techniques, such 
as pitfall traps and active searching. We used a bootstrap method to estimate the species richness of the local herpetofauna. We also calculated dominance and evenness indices. We recorded 3,969 specimens of 49 species. Snakes had the highest species richness, while lizards were more abundant. Anurans comprised $14 \pm 0.8$ species, with high evenness $\left(\mathrm{J}^{\prime}=65.8 \%\right)$ and low dominance $(\mathrm{D}=23.3 \%)$. The number of squamate species was the same as the amount observed $(\mathrm{n}=36)$, and also had high evenness $\left(\mathrm{J}^{\prime}=55.7 \%\right)$ and low dominance $(\mathrm{D}=23.9 \%)$. In general, the studied area showed a pattern of evenness with low dominance, in addition to environmental stability, which is a characteristic of most conserved environments and leads us to stress the importance of this region to the maintenance of the biodiversity of the Caatinga biome.

Key words: Amphibians; Caatinga; Conservation; Priority areas; Reptiles

\section{Introduction}

The Caatinga is a biome that contains forests and shrublands consisting mainly of small trees and shrubs, with stony soils and an arid climate with low and irregular rainfall (PRADO, 2003; QUEIROZ et al., 2017). It is an exclusively Brazilian biome, encompassing an approximate area of $800,000 \mathrm{~km}^{2}$, which represents $11 \%$ of the national territory. Most of its territory is located in northeastern Brazil, with the exception of some areas situated in the northern end of the state of Minas Gerais (BUCHER, 1982; LEAL et al., 2005; SILVA et al., 2017). Little is known about the biodiversity of the Caatinga, and it is likely that the species richnesses of many groups are still underestimated (SILVA et al., 2004). This lack of knowledge led this region to be perceived as having low richness and endemism, and as suffering few anthropogenic impacts. However, recent advances in research disprove this notion (SILVA et al., 2004).

Currently the Caatinga is considered the richest semiarid biome, with high endemism, and anthropogenic pressures on it grow exponentially (SILVA; BARBOSA, 2017). Even so, there are few studies about its biological diversity. Most of the region was poorly sampled, which limits any existing knowledge of its biodiversity and directly affects the implementation of effective management strategies for biodiversity conservation (FREITAS; VERÍSSIMO, 2012). Because of these deficient conservation strategies, only a small number of protected areas have been created in the Caatinga (TABARELLI; VICENTE, 2002). Considering all of the protected areas in Brazil, public and private, only $8.53 \%$ of the protected territory is located in this biome (MMA, 2018). Besides being small in number and size, most of these conservation units do not have an adequate infrastructure for researchers, which makes it even more difficult to develop scientific reports on the region, such as biological inventories, and to create management and conservation plans (TABARELLI; VICENTE, 2002).

In light of this issue, inventories of areas of the Caatinga - especially areas that have never been studied before - are essential to understand the constitution of these environments and the biodiversity in them. This could not be different with regard to their herpetofauna. A study by Rodrigues (2003) estimated that a total of 167 species live in the whole Caatinga area. Since its publication, many surveys have been conducted in the Caatinga, adding 85 species of amphibians and reptiles to this total (ALBUQUERQUE et al., 2012; GARDA et al., 2017; MESQUITA et al., 2017).

Despite increased recognition of the species richness of the Caatinga herpetofauna over the years, the facts above clearly demonstrate that this group is still insufficiently known, since many areas of the Caatinga remain unexplored and its conservation is directly hampered by this deficiency. Here we publish, for the first time, the species composition, richness and threat status (IUCN) of amphibians and reptiles from the municipality of Nordestina, as well as an evaluation of the conditions necessary to preserve this area, which until now was considered an unknown area for conservation.

\section{Materials and Methods}

This study was carried out in a semiarid area, at a site owned by Lipari Mineração LTDA (10 54 '7.96”'S, $\left.39^{\circ} 25^{\prime} 20.64^{\prime \prime} \mathrm{W}\right)$, which occupies approximately 664.71 acres within the municipality of Nordestina, in the northern region of the state of Bahia, in Brazil 
(Figure 1). The species records used in this study refer to the fauna rescue and monitoring programs done by Lipari Mineração LTDA during its business license acquisition process (INEMA license no ${ }^{\circ} .589 / 2014$ ) and start of operations (INEMA license $n^{\circ}$ 12.591/2016), which occurred in two distinct periods: January to April, 2015, and March to October, 2016, resulting in a total of 12 months of sampling, including the dry and rainy seasons.

The data were collected using a passive technique called pitfall trap and direct methods such as active searching followed by hand capture. Pitfall traps are recommended for this type of study, since they facilitate the registration of specimens that are difficult to find by visual search. During the carrying out of the fauna rescue and monitoring programs 440 pitfall traps were installed, distributed among 110 stations throughout the study area. Each station contained four 30-liter buckets arranged in a Y shape. Each station operated only once, for seven days, thus generating a sampling effort of 3,080 days in total.
The second technique, active searching, was used during the fauna rescue program. While the process of mechanized deforestation was being performed, two samplers captured the specimens that appeared. This activity lasted 52 weeks (from Monday to Friday) during the two previously mentioned periods (January-April, 2015, and March-October, 2016). Thus, the sampling effort consisted of 260 days of active searching (nine hours per day). All of the captured specimens were released in the protected area belonging to Lipari Mineração LTDA, beside the study area and with similar environmental characteristics.

To estimate the species richness of the herpetofauna, we produced rarefaction curves from 1,000 randomizations of sampling order. Thus, it was possible to assess the representativeness of the sample. We used species richness data in these analyses, and each week of field work corresponded to a sample, resulting in 52 samples for the studied area. We used presence/ absence data in a bootstrap estimator to determine

FIGURE 1: Location of Nordestina in the state of Bahia, Brazil. The photos to the side represent the different environments in the study area. From top to bottom: shrubland, rupestrian grasslands and wetlands.

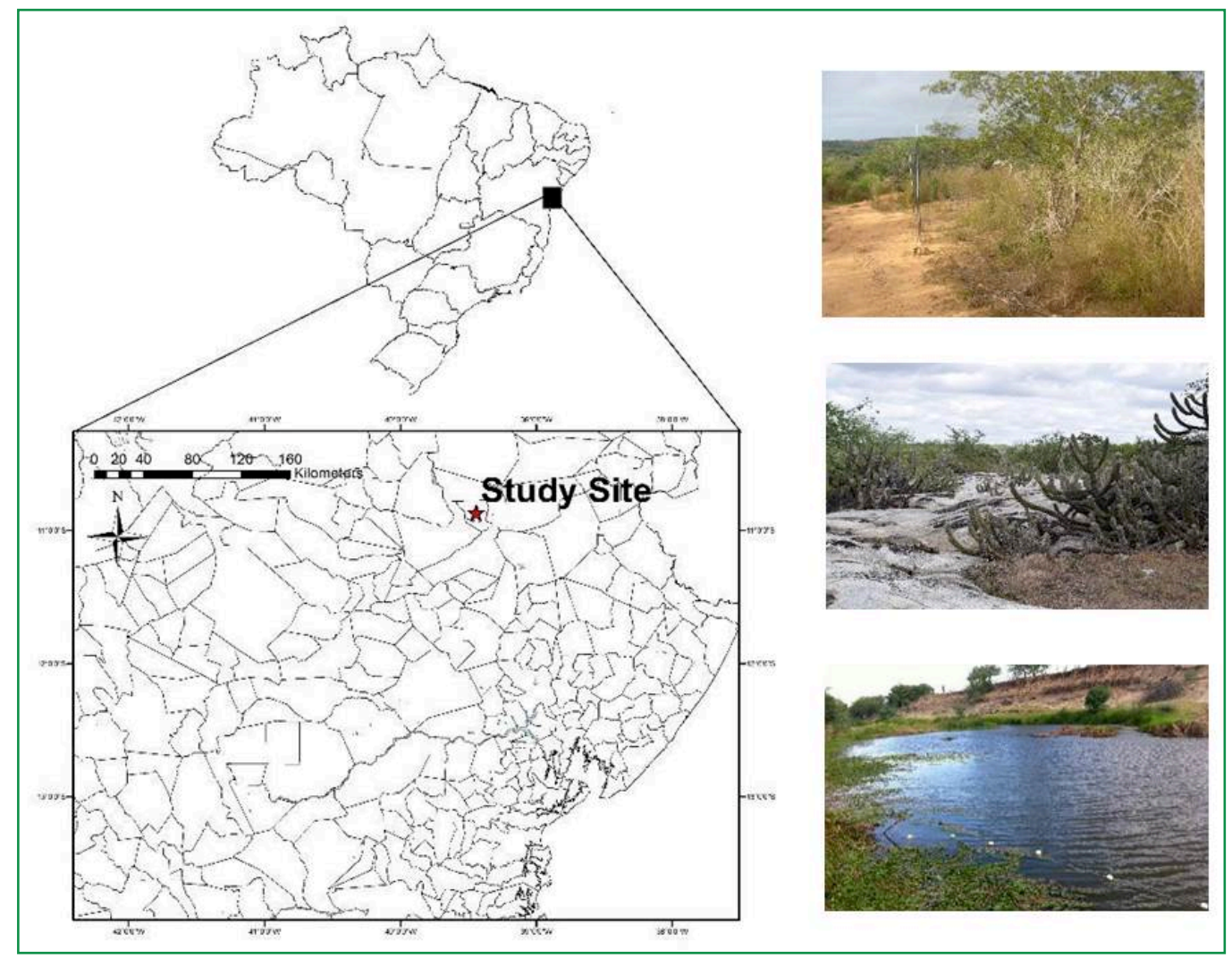


the expected richness of amphibians and reptiles. This estimator uses data from all collected species to estimate their total richness and is not restricted to rare species. The rarefaction curves were generated in EstimateS, v. 9.1.0 (COLWELL, 2013). Also, we evaluated the total dominance in the area (using a 1-Simpson index), and we employed Pielou's index (J') as an evenness measure (MAGURRAN, 2004) to evaluate the preservation conditions of the area, since more conserved environments tend to have greater evenness and lower dominance (MAGURRAN, 2004). The analyses described above were performed using Past, v. 2.17 (HAMMER et al., 2001).

\section{Results}

During the fauna rescue process, 3,969 individuals were recorded and distributed among 49 species (Table 1). Between those, snakes had the greater richness $(n=16)$; followed by lizards $(n=15)$; anurans $(\mathrm{n}=13)$; testudines $(\mathrm{n}=3)$; and amphisbaenians $(n=2)$. With regard to abundance, lizards had the largest number of individuals $(\mathrm{n}=3,022)$; followed by anurans, with 614 individuals; snakes, with 192 individuals; amphisbaenians, with 132 individuals; and, finally, testudines, with nine individuals sampled (Table 1). Three species were represented by a single individual (singletons): Chelonoidis carbonaria (Spix, 1824), Leptodactylus vastus Lutz, 1930 and Oxybelis aeneus (Wagler, 1824); and two species were represented by two individuals (doubletons): Leptophis ahaetulla ahaetulla (Linnaeus, 1758) and Xenodon merremii (Wagler, 1824).

The rarefaction curves of both groups, amphibians and squamates, tended to asymptotes, which suggests that most herpetofauna species were recorded. A total of 13 species of anurans were observed, which is very close to the value suggested by the bootstrap estimator: $\mathrm{n}=14 \pm 0.8$ (Figure 2A). The estimated richness of squamates, on the other hand, was of $36 \pm 1.3$ species, the same amount as the one observed (Figure 2B).

TABLE 1: List of anurans, testudines and squamates (lizards, amphisbaenians and snakes) recorded in this study, in Nordestina, northeastern Bahia, Brazil. Threat status by IUCN - International Union for Conservation of Nature: Not Evaluated (NE), Data Deficient (DD) and Least Concern (LC). Sampling techniques: Pitfall Trap (PT) and Active Search (AS).

\begin{tabular}{|c|c|c|c|c|}
\hline \multirow{2}{*}{$\begin{array}{c}\text { Taxa } \\
\text { Anura }\end{array}$} & \multirow[t]{2}{*}{$\begin{array}{c}\text { Total number of } \\
\text { individuals }\end{array}$} & \multirow[t]{2}{*}{ IUCN } & \multicolumn{2}{|c|}{$\begin{array}{c}\text { Sampling } \\
\text { Techniques }\end{array}$} \\
\hline & & & PT & AS \\
\hline \multicolumn{5}{|l|}{ Bufonidae } \\
\hline Rhinella granulosa (Spix, 1824) & 199 & $\mathrm{LC}$ & $\mathrm{x}$ & $\mathrm{x}$ \\
\hline Rhinella jimi (Stevaux, 2002) & 7 & $\mathrm{LC}$ & $\mathrm{x}$ & $\mathrm{x}$ \\
\hline \multicolumn{5}{|l|}{ Hylidae } \\
\hline Corythomantis greeningi Boulenger, 1896 & 3 & $\mathrm{LC}$ & & $\mathrm{x}$ \\
\hline Scinax gr. ruber & 4 & NE & & \\
\hline Scinax $x$-signatus (Spix, 1824) & 41 & $\mathrm{LC}$ & $\mathrm{x}$ & $\mathrm{x}$ \\
\hline \multicolumn{5}{|l|}{ Leptodactylidae } \\
\hline Leptodactylus macrosternum Miranda-Ribeiro, 1926 & 3 & $\mathrm{LC}$ & $\mathrm{x}$ & $\mathrm{x}$ \\
\hline Leptodactylus troglodytes Lutz, 1926 & 3 & $\mathrm{LC}$ & $\mathrm{x}$ & $\mathrm{x}$ \\
\hline Leptodactylus vastus Lutz, 1930 & 1 & $\mathrm{LC}$ & & $\mathrm{x}$ \\
\hline Physalaemus sp. & 53 & $\mathrm{NE}$ & $\mathrm{x}$ & $\mathrm{x}$ \\
\hline Pleurodema diplolister (Peters, 1870) & 176 & $\mathrm{LC}$ & $\mathrm{x}$ & $\mathrm{x}$ \\
\hline \multicolumn{5}{|l|}{ Microhylidae } \\
\hline Dermatonotus muelleri (Boettger, 1885) & 112 & $\mathrm{LC}$ & $\mathrm{x}$ & $\mathrm{x}$ \\
\hline
\end{tabular}




\section{Odontophrynidae}

Proceratophrys cristiceps (Müller, 1884)

8

LC $\quad \mathrm{x} \quad \mathrm{x}$

Phyllomedusidae

Pithecopus nordestinus Caramaschi, 2006

4

DD

$\mathrm{x}$

Testudines

Chelidae

Phrynops geoffroanus (Schweigger, 1812)

Mesoclemmys tuberculata (Lüderwaldt, 1926)

$\begin{array}{lll}5 & \text { NE } & x \\ 3 & \text { NE } & x\end{array}$

\section{Testudinidae}

Chelonoidis carbonaria (Spix, 1824)

$\mathrm{x}$

\section{Squamata}

\section{Gekkonidae}

Hemidactylus cf. agrius Vanzolini, 1978

Hemidactylus brasilianus (Amaral, 1935)

\begin{tabular}{|c|c|c|c|}
\hline 15 & $\mathrm{NE}$ & & $\mathrm{X}$ \\
\hline 45 & $\mathrm{NE}$ & & $\mathrm{X}$ \\
\hline 24 & $\mathrm{NE}$ & & $\mathrm{X}$ \\
\hline 22 & $\mathrm{NE}$ & & $\mathrm{X}$ \\
\hline 24 & $\mathrm{NE}$ & $\mathrm{x}$ & $\mathrm{X}$ \\
\hline 25 & $\mathrm{NE}$ & & $\mathrm{x}$ \\
\hline 21 & $\mathrm{NE}$ & $\mathrm{x}$ & $\mathrm{x}$ \\
\hline 247 & $\mathrm{NE}$ & $\mathrm{x}$ & $\mathrm{X}$ \\
\hline 180 & $\mathrm{NE}$ & & $\mathrm{X}$ \\
\hline 40 & $\mathrm{NE}$ & & $\mathrm{x}$ \\
\hline 1243 & $\mathrm{NE}$ & $\mathrm{x}$ & $\mathrm{x}$ \\
\hline 15 & $\mathrm{LC}$ & $\mathrm{X}$ & $\mathrm{X}$ \\
\hline 91 & $\mathrm{NE}$ & $\mathrm{x}$ & $\mathrm{X}$ \\
\hline 1013 & $\mathrm{NE}$ & $\mathrm{x}$ & $\mathrm{x}$ \\
\hline 17 & $\mathrm{LC}$ & $\mathrm{x}$ & $\mathrm{x}$ \\
\hline 60 & $\mathrm{NE}$ & & $\mathrm{X}$ \\
\hline 72 & $\mathrm{LC}$ & & $\mathrm{x}$ \\
\hline 4 & $\mathrm{NE}$ & & $\mathrm{X}$ \\
\hline 4 & $\mathrm{NE}$ & & $\mathrm{x}$ \\
\hline 16 & $\mathrm{NE}$ & $\mathrm{x}$ & $\mathrm{X}$ \\
\hline 6 & $\mathrm{NE}$ & & $\mathrm{X}$ \\
\hline
\end{tabular}

Lygodactylus klugei (Smith, Martin \& Swain, 1977)

\section{Gymnophthalmidae}

Acratosaura mentalis (Amaral, 1933)

Vanzosaura multiscutata (Amaral, 1933)

\section{Iguanidae}

Iguana iguana iguana (Linnaeus, 1758)

\section{Mabuyidae}

Brasiliscincus heathi (Schmidt \& Inger, 1951)

\section{Phyllodactylidae}

Gymnodactylus geckoides Spix, 1825

Phyllopezus pollicaris pollicaris (Spix, 1825)

\section{Polychrotidae}

Polychrus acutirostris Spix, 1825

\section{Teiidae}

Ameivula nigrigula (Arias, de Carvalho, Rodrigues \& Zaher, 2011)

Salvator merianae Duméril \& Bibron, 1839

\section{Tropiduridae}

Tropidurus sp.

Tropidurus hispidus (Spix, 1825)

Tropidurus semitaeniatus (Spix, 1825)

\section{Amphisbaenidae}

Amphisbaena cf. vermicularis (Wagler, 1824)

Leposternon polystegum (Duméril, 1851)

\section{Boidae}

Boa constrictor constrictor Linnaeus, 1758

Epicrates assisi Machado, 1945

\section{Colubridae}

Apostolepis cearensis Gomes, 1915

Boiruna sertaneja Zaher, 1996

1

$\mathrm{NE}$ 
Leptophis ahaetulla ahaetulla (Linnaeus, 1758)

Oxybelis aeneus (Wagler, 1824)

Oxyrhopus trigeminus Duméril, Bibron \& Duméril, 1854

Philodryas nattereri Steindachner, 1870

Philodryas olfersii Lichtenstein, 1823

Pseudoboa nigra (Duméril, Bibron \& Duméril, 1854)

Thamnodynastes cf. pallidus (Linnaeus, 1758)

Thamnodynastes $\mathrm{sp}$.

Xenodon merremii (Wagler, 1824)

\begin{tabular}{ccc}
2 & NE & $\mathrm{x}$ \\
1 & $\mathrm{NE}$ & $\mathrm{x}$ \\
65 & $\mathrm{NE}$ & $\mathrm{x}$ \\
30 & $\mathrm{NE}$ & $\mathrm{x}$ \\
5 & $\mathrm{NE}$ & $\mathrm{x}$ \\
15 & $\mathrm{NE}$ & $\mathrm{x}$ \\
6 & $\mathrm{LC}$ & $\mathrm{x}$ \\
17 & $\mathrm{NE}$ & $\mathrm{x}$ \\
2 & $\mathrm{NE}$ & $\mathrm{x}$ \\
& & \\
4 & $\mathrm{LC}$ & $\mathrm{x}$ \\
& & \\
11 & $\mathrm{LC}$ & $\mathrm{x}$ \\
4 & $\mathrm{LC}$ & $\mathrm{x}$ \\
\hline
\end{tabular}

\section{Elapidae}

Micrurus lemniscatus lemniscatus (Linnaeus, 1758)

\section{Viperidae}

Bothrops erythromelas Amaral, 1923

Crotalus durissus ( Lineu, 1758)

FIGURE 2: Rarefaction curves of anurans (A) and squamates (B) sampled in Nordestina, northeastern Bahia, Brazil, created from 1000 randomizations. The red-dotted line represents the observed species richness, while the black line represents the species richness suggested by the bootstrap estimator.

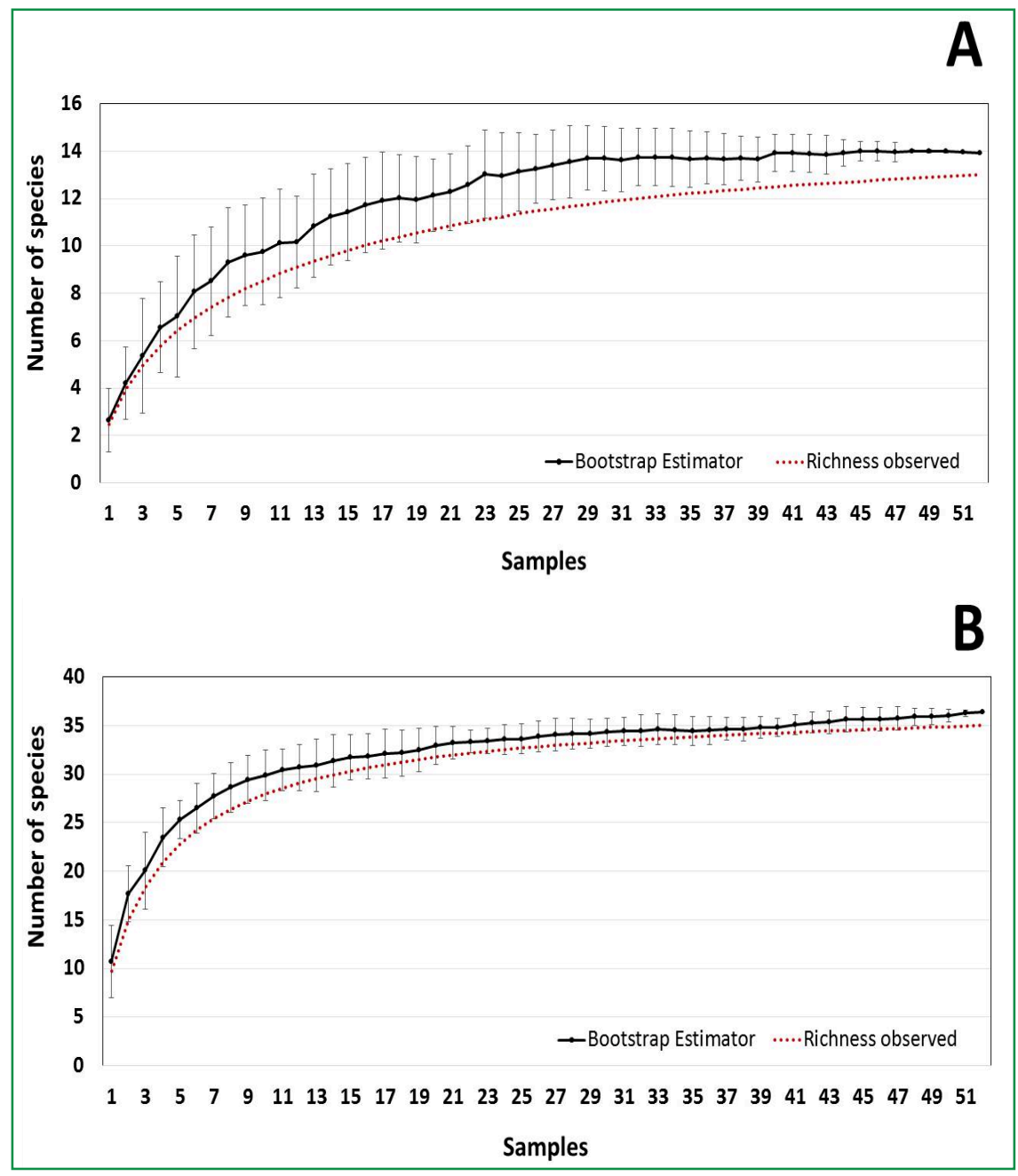


Additionally, the diversity parameters complemented the observation of the pattern of the local herpetofauna. Thus, it was possible to observe that anurans had high evenness $\left(\mathrm{J}^{\prime}=65.8 \%\right)$ and low dominance $(\mathrm{D}=23.3 \%)$, with $R$. granulosa as the dominant species, representing $32.4 \%$ of anuran records. Squamates showed a similar pattern, with high evenness $\left(\mathrm{J}^{\prime}=55.7 \%\right)$ and low dominance $(\mathrm{D}=23.9 \%)$, and $A$. nigrigula as the dominant taxon (representing $37 \%$ of squamate records).

\section{Discussion}

During this period, the two most common species were A. nigrigula and T. hispidus, with 1,243 and 1,013 individuals, respectively. According to Rodrigues (2003), both species are heliothermic and have good adaptability in open areas with hot and dry climates. The Caatinga has both of these characteristics, thus favoring the survival of those species, which may explain the high abundance of them observed in this study. Despite these two species being highly abundant when compared with others, in general, the area demonstrated high evenness with low dominance. As suggested by Magurran (2004), that is a characteristic of preserved areas, which leads us to stress the importance of the Nordestina region to the maintenance of the biodiversity of the Caatinga.

Based on a compilation of studies about the herpetofauna of the Caatinga, a total of 239 species was listed (ALBUQUERQUE et al., 2012; GARDA et al., 2017; MESQUITA et al., 2017). The species richness of the Nordestina municipality observed in the present study corresponds to approximately $20.5 \%$ of this total (49 species). Also, the richness found at the studied site is similar to that of protected areas in the Caatinga: the Serra da Capivara National Park (37 species; CAVALCANTI et al., 2014), Seridó Ecological Station (41 species; CALDAS et al., 2016), Raso da Catarina Ecological Station (53 species; GARDA et al., 2013), Aiuaba Ecological Station (57 species, COSTA et al., 2018), the Catimbau National Park (58 species; PEDROSA et al., 2014) and the northern portion of the Chapada Diamantina National Park, located in the municipality of Palmeiras (75 species; MAGALHÃES et al., 2015).

Despite the high richness found in this study, none of the species cited here is included on the Red List of Threated Species (IUCN, 2019) or the Red Book of Threatened Species of Fauna of Brazil (MMA, 2018), and most of them have not been assessed or appear as deficient data. Fauna inventories, such as the present study, can help to change the current situation, since they provide relevant contributions to the evaluation of the species richness of still unexplored areas.

Furthermore, the scarcity of studies on the Caatinga has influenced the policies geared toward the conservation of its biological diversity (TABARELLI; SILVA, 2003). Consequently, there are only a small number of protected areas in the region (TABARELLI; VICENTE, 2002), while anthropogenic pressures increase (SILVA; BARBOSA, 2017). Recently, the Ministry of Environment of Brazil (MMA, 2016) updated the priority areas for conservation in the Caatinga. The total number of priority areas is 282 . Despite the reduction of 10 areas since the last update (MMA, 2007), there are two priority areas on the list that are located near the site of this study. The most distant area is $80 \mathrm{~km}$ away from the study site and was classified as a High Importance area ( $\mathrm{Ca} 027)$, while the other area was classified as Insufficiently Known Importance (Ca032) and is approximately $62 \mathrm{~km}$ away from the site (Figure 3). These facts reinforce the importance of these two regions to the conservation of biodiversity in the Caatinga and the relevance of our results, since the high biodiversity found here offers new scientific knowledge of the region, which may aid in the implementation of conservation plans in the two priority areas near the study site.

Finally, our results demonstrate that environmental licensing programs provide important data on local biodiversity, as also observed in other studies that used data from environmental licensing programs and thus resulted in new fauna inventories (COUTO-FERREIRA et al., 2011; MARQUES et al., 2011; MOTA et al., 2012), new knowledge of fauna distribution extension (MELO et al., 2014) and landscape ecology for management strategies (MENEZES et al., 2007). Therefore, we 
recommend that the results obtained by environmental licensing are published, as they can contribute greatly to the knowledge of areas that are still little sampled, and may serve as a basis for guides on the species of this biome, similarly to what is done in this study (Figure 4-49).

FIGURE 3: Priority areas for biodiversity conservation in the Caatinga. On the map, their geographical proximity to the study site can be clearly noted (MMA, 2007).

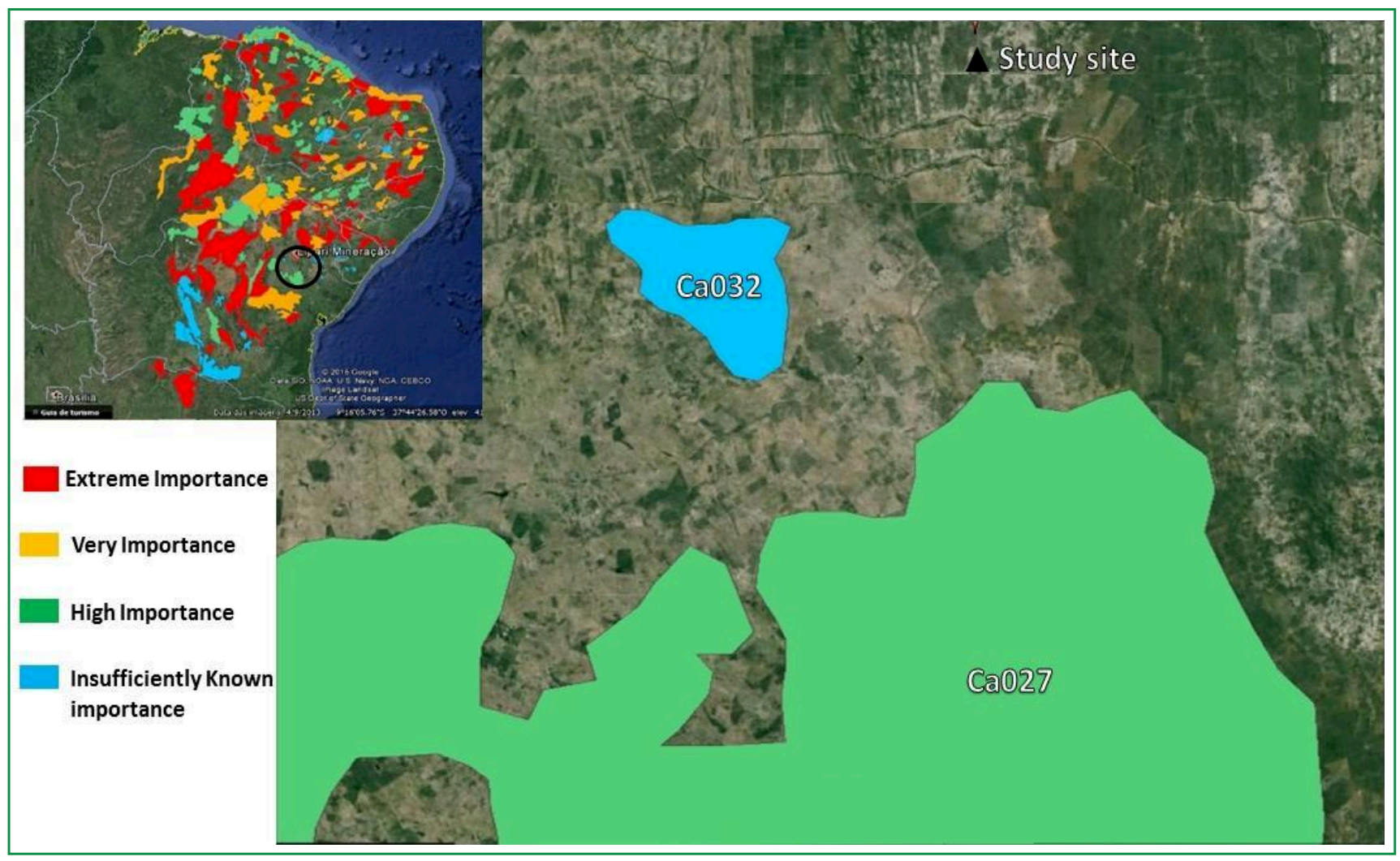


FIGURE 4-15: Anurans collected in the Nordestina municipally: 4. Rhinella granulosa; 5. Rhinella jimi; 6. Corythomantis greening; 7. Pithecopus nordestinus; 8. Scinax x-signatus; 9. Leptodactylus macrosternum; 10. Leptodactylus troglodytes; 11. Leptodactylus vastus; 12. Physalaemus sp.; 13. Pleurodema diplolister; 14. Dermatonotus muelleri; 15. Proceratophrys cristiceps.
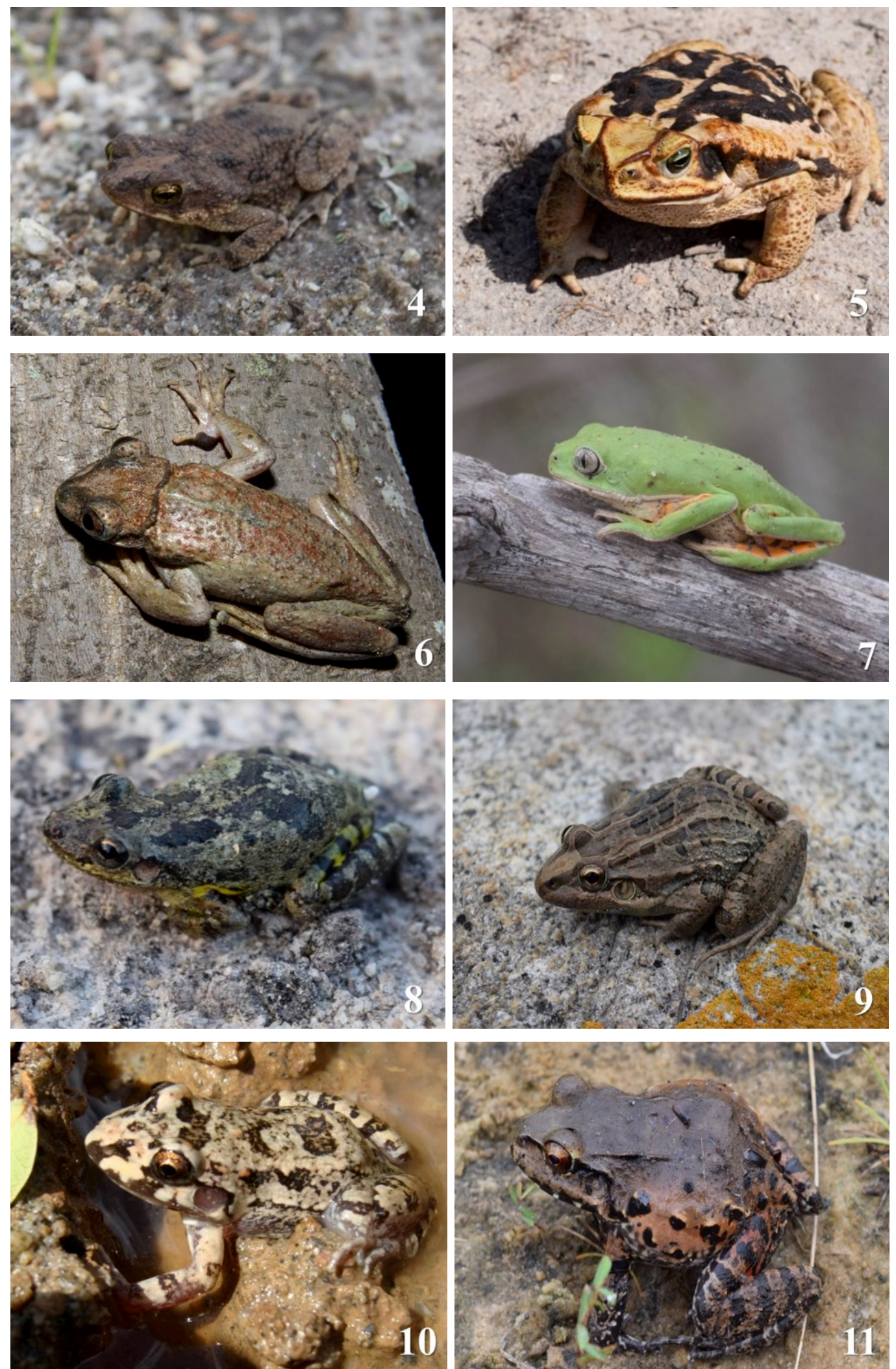

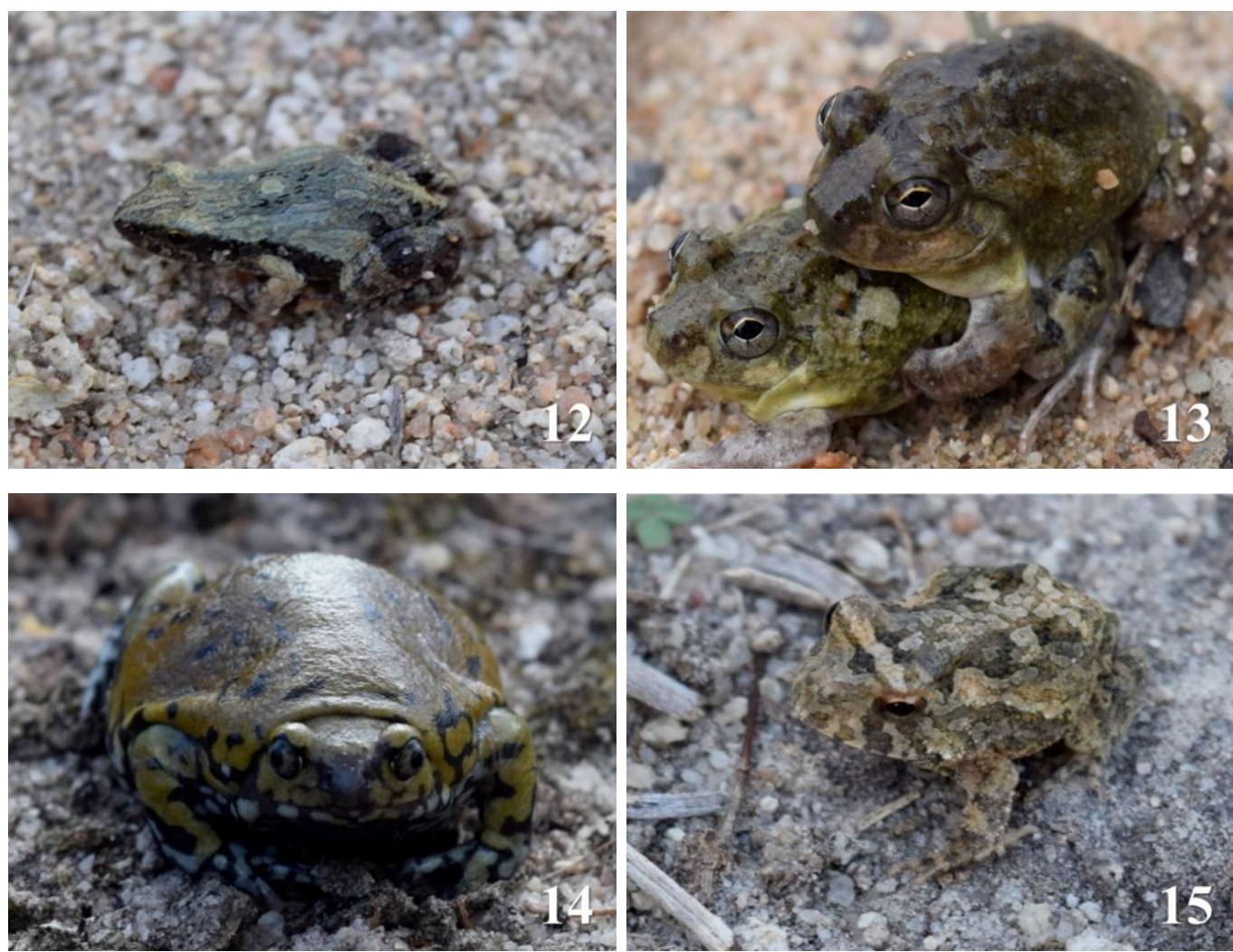

FIGURE 16-18: Testudines collected in Nordestina municipally: 16. Phrynops geoffroanus; 17. Mesoclemmys tuberculata; 18. Chelonoidis carbonaria.
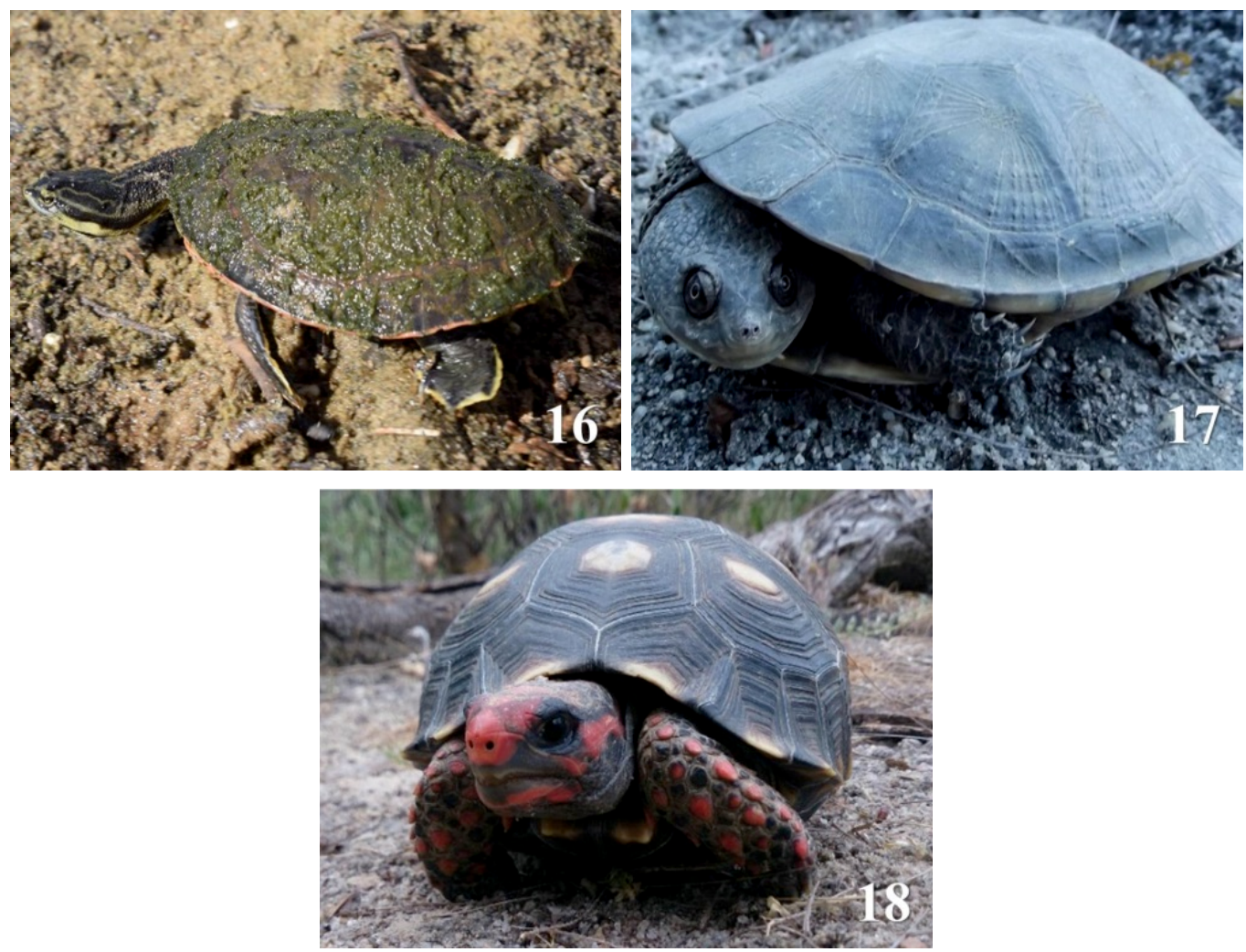
FIGURE 19-49: Squamates collected at Nordestina municipally: 19. Hemidactylus brasilianus; 20. Lygodactylus klugei; 21. Acratosaura mentalis; 22. Vanzosaura multiscutata; 23. Iguana i. iguana; 24. Brasiliscincus heathi; 25. Gymnodactylus geckoides; 26. Phyllopezus p. pollicaris; 27. Polychrus acutirostris; 28. Ameivula nigrigula; 29. Salvator merianae; 30. Tropidurus hispidus; 31. Tropidurus semitaeniatus; 32. Amphisbaena cf. vermicularis; 33. Leposternon polystegum; 34. Boa c. constrictor; 35. Epicrates assisi; 36. Apostolepis cearensis; 37. Boiruna sertaneja; 38. Leptophis a. ahaetulla; 39. Oxybelis aeneus; 40. Oxyrhopus trigeminus; 41. Philodryas nattereri; 42. Philodryas olfersii; 43. Pseudoboa nigra; 44. Thamnodynastes cf. pallidus; 45. Thamnodynastes sp.; 46. Xenodon merremii; 47. Micrurus l. lemniscatus; 48. Bothrops erythromelas; 49. Crotalus durissus.
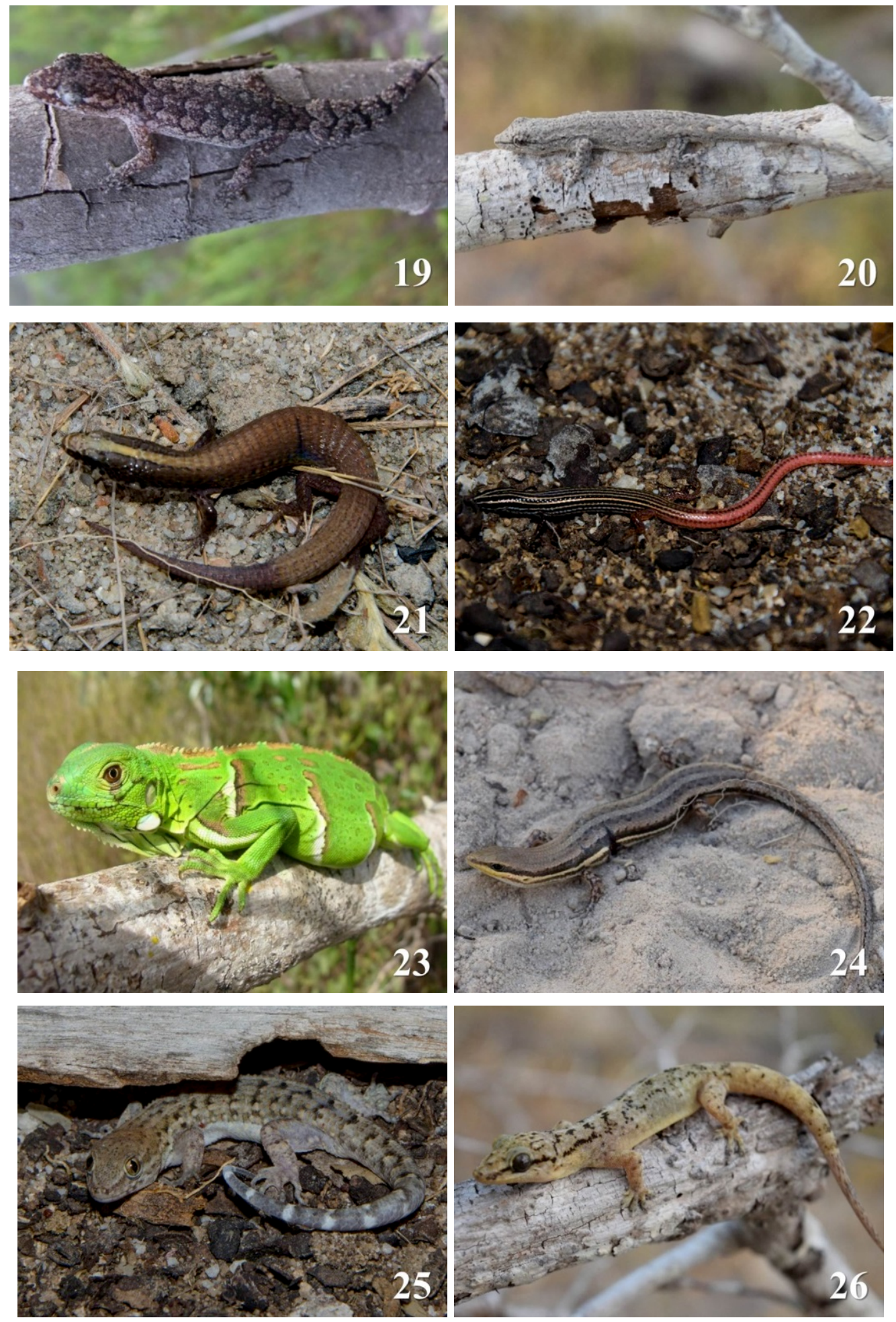

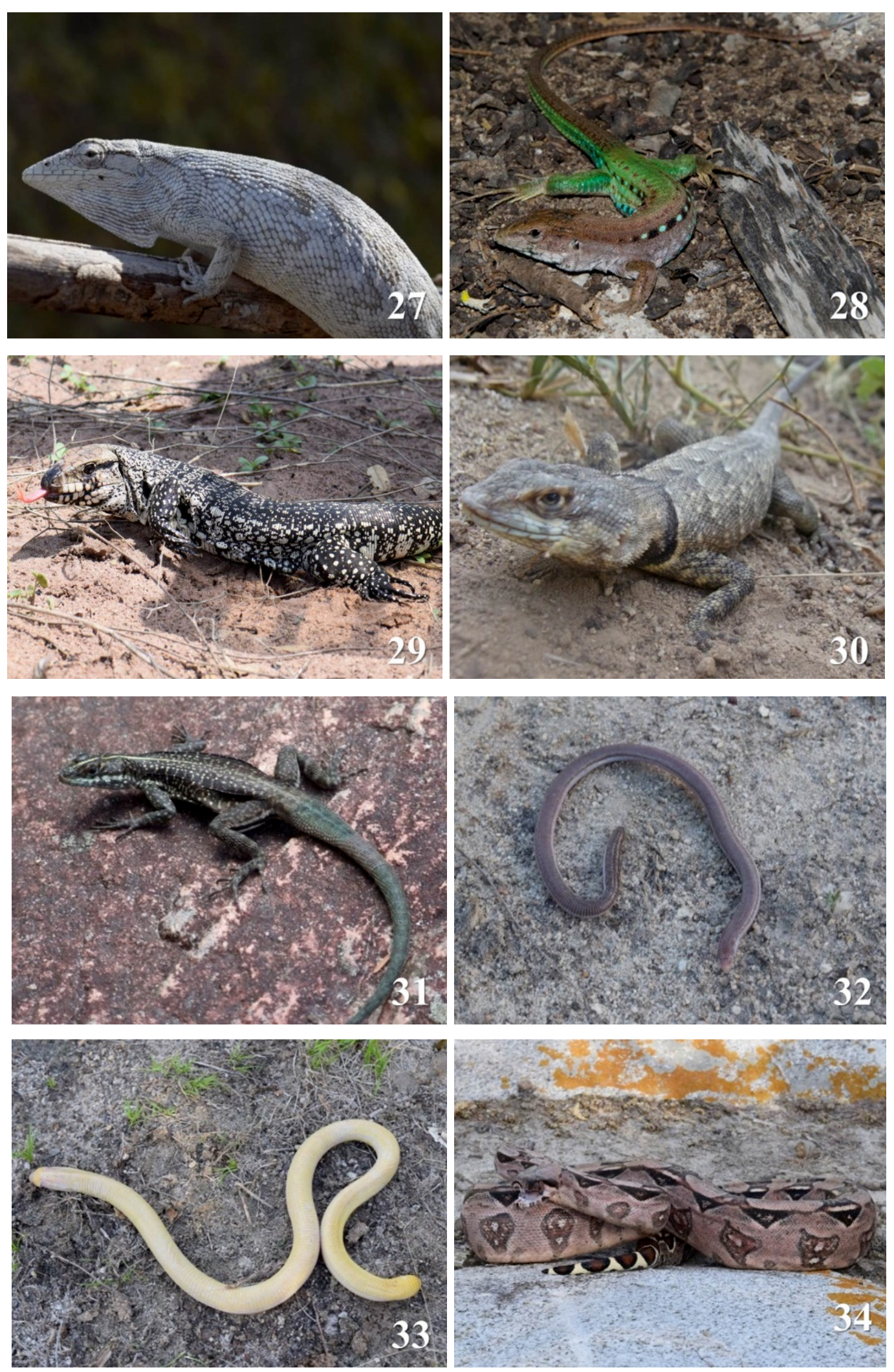

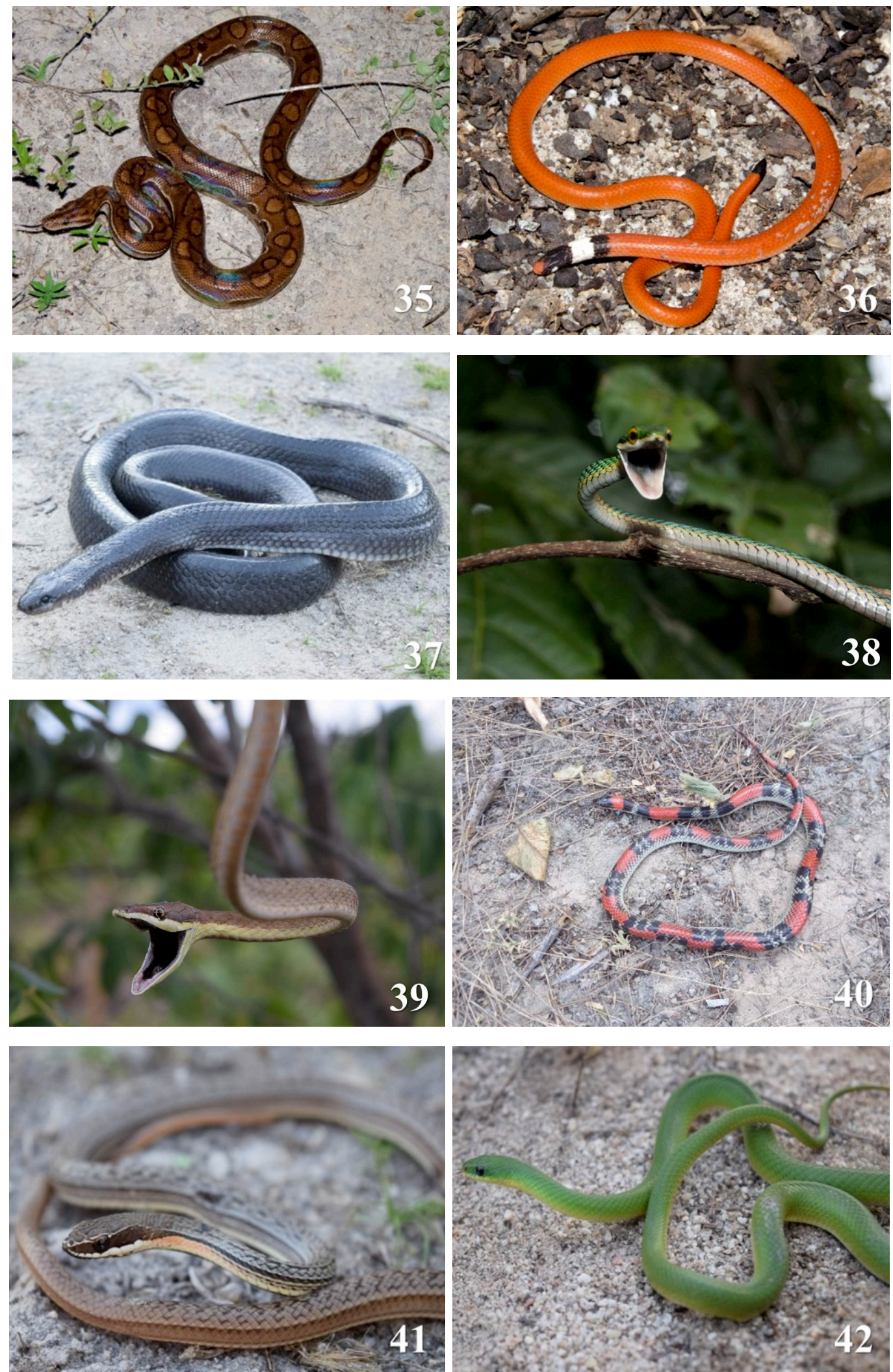

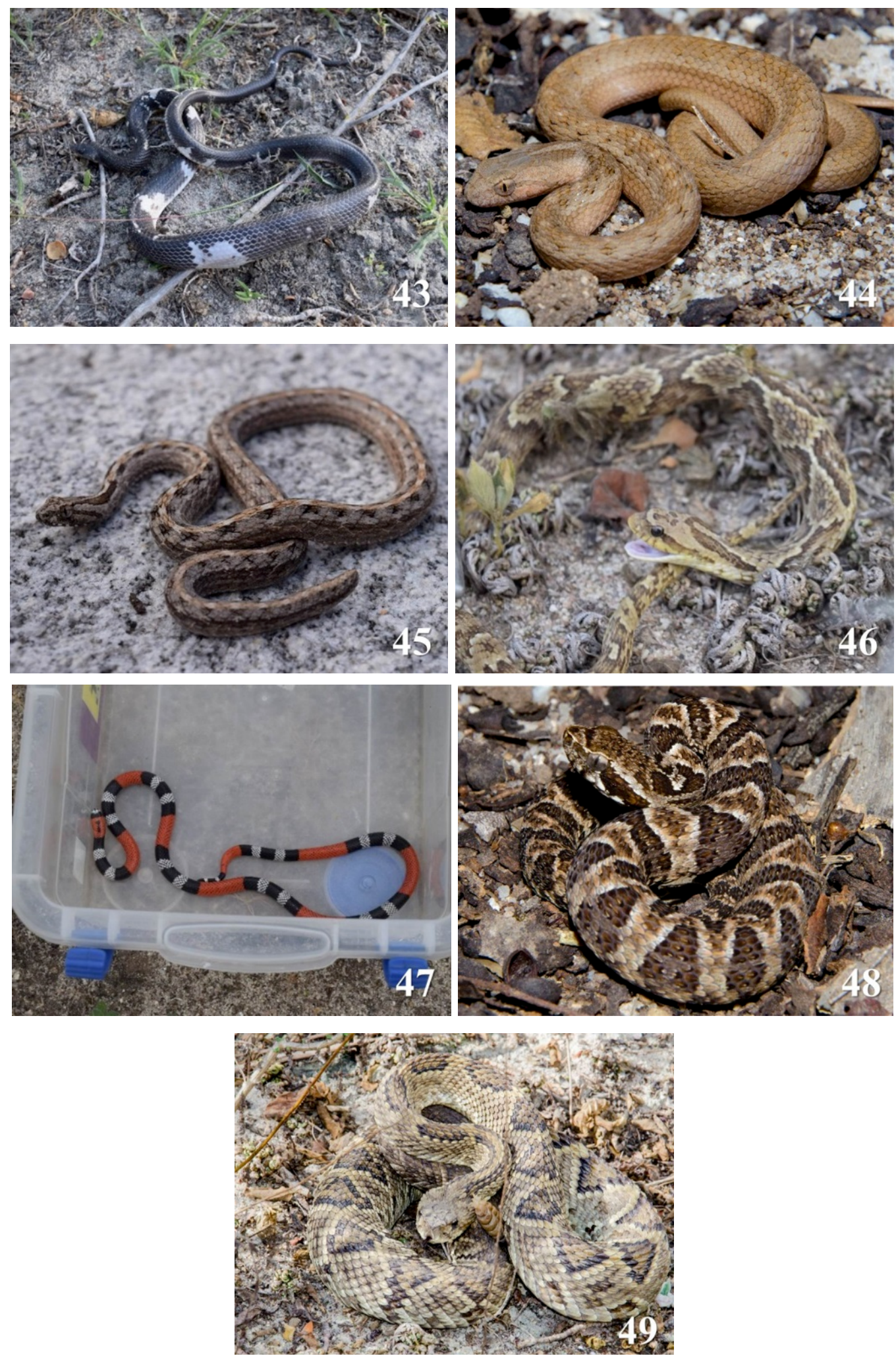


\section{Acknowledgements}

To Lipari Mineração LTDA for encouraging research in the region and authorizing the publication of these data. We would also like to thank Lacerta Consultoria, Projetos e Assessoria Ambiental LTDA for providing an adequate infrastructure to conduct this study.

\section{References}

ALBUQUERQUE, U. P.; LIMA ARAÚJO, E. de; EL-DEIR, A. C. A.; LIMA, A. L. A.; SOUTO, A.; BEZERRA, B. M.; FERRAZ, E. M. N.; FREIRE, E. M. X.; SAMPAIO, E. V. S. B.; LAS-CASAS, F. M. G.; MOURA, G. J. B.; PEREIRA, G. A.; MELO, J. G.; RAMOS, M. A.; RODAL, M. J. N.; SCHIEL, N.; LYRA-NEVES, R. M.; ALVES, R. R. N.; AZEVEDO-JÚNIOR, S. M.; TELINO JÚNIOR, W. R.; SEVERI, W. Caatinga revisited: ecology and conservation of an important seasonal dry forest. Scientific World Journal, Nars City, v. 2012, p. 2-19, 2012.

BUCHER, E. H. Chaco and caatinga - South American arid savannas, woodlands and thickets. In: HUNTEY, B. J.; WALTHER, B. H. (Ed.). Ecology of tropical savanas. New York: SpringerVerlag, 1982. p. 48-79.

CALDAS, F. L. S.; COSTA, T. B.; LARANJEIRAS, D. O.; MESQUITA, D. O.; GARDA, A. A. Herpetofauna of protected areas in the Caatinga V: Seridó Ecological Station (Rio Grande do Norte, Brazil). Check List, Rio Claro, v. 12, n. 4, p. 1-14, 2016.

CAVALCANTI, L. B. Q.; COSTA, T. B.; COLli, G. R.; COSTA, G. C.; FRANÇA, F. G. R.; MESQUITA, D. O.; PALMEIRA, C. N. S.; PELEGRIN, N.; SOARES, A. H. B.; TUCKER, D. B.; GARDA, A. A. Herpetofauna of protected areas in the Caatinga II: Serra da Capivara National Park, Piauí, Brazil. Checklist, Rio Claro, v. 10, n. 1, p. 18-27, 2014.

COLWELL, R. K. EstimateS, Version 9.1: statistical estimation of species richness and shared species from samples. Software and User's Guide. 2013. Available in: <http://viceroy.eeb.uconn.edu/ estimates/>.

COSTA, T. B.; LARANJEIRAS, D. O.; CALDAS, F. L. S.; SANTANA, D. O.; SILVA, C. F.; ALCÂNTARA, E. P.; BRITO, S. V.; GALDINO, J. Y.; MESQUITA, D. O.; FARIA, R. G.; FRANÇA, F. G. R.; ÁVILA, R. W.; GARDA, A. A. Herpetofauna of protected areas in the Caatinga VII: Aiuaba Ecological Station (Ceará, Brazil). Herpetology Notes, Pisa, v. 11, p. 929-941. 2018.

COUTO-FERREIRA, D.; TINÔCO, M. S.; OLIVEIRA, M. L. T.; BROWNE-RIBEIRO, H. C.; FAZOLATO, C. P., SILVA, R. M., BARRETO, G. S.; DIAS, M. A. Restinga lizards (Reptilia: Squamata) at the Imbassaí Preserve on the northern coast of Bahia, Brazil. Journal of Threatened Taxa, New Delhi, v. 3, n. 8, p. 1990-2000, 2011.

FREITAS, M. A.; VERÍSSIMO, D. First record of the lizard Procellosaurinus erythrocercus (Rodrigues, 1991), (Squamata: Gymnophtalmidae) for the Brazilian state of Piauí, Brazil. Herpetology Notes, Pisa, v. 5, p. 35-36, 2012.
GARDA, A. A.; COSTA, T. B.; SANTOS-SILVA, C. R.; MESQUITA, D. O.; FARIA, R. G.; CONCEIÇÃO, B. M.; SILVA, I. R. S.; FERREIRA, A. S.; ROCHA, S. M.; PALMEIRA, C. N. S.; RODRIGUES, R.; FERRARI, S. F.; TORQUATO, S. Herpetofauna of protected areas in the Caatinga I: Raso da Catarina Ecological Station (Bahia, Brazil). Check List, Rio Claro, v. 9, n. 2, p. 405414, 2013.

GARDA, A. A.; STEIN, M. G.; MACHADO, R. B.; LION, M. B.; JUNCÁ, F. A.; NAPOLI, M. F. Ecology, biogeography, and conservation of amphibians of the Caatinga. In: SILVA, J. M. C.; LEAL, I. R.; TABARELLI, M. (Ed.). Caatinga: the largest tropical dry forest region in South America. 1. ed. New York: Springer, 2017. p. 133-149.

HAMMER, Ø.; HARPER, D. A. T.; RYAN, P. D. PAST: Paleontological statistics software package for education and data analysis. Palaeontologia Electronica, Oslo, v. 4, n. 1, p. 1-9, 2001. IUCN. IUCN red list of threatened species. 2019. Available in: $<$ Www.iucnredlist.org $>$.

LEAL, I. R.; SILVA, J. M. C.; TABARELLI, M.; LACHER-JR, T. E. Mudando o curso da conservação da biodiversidade na Caatinga do Nordeste do Brasil. Megadiversidade, Belo Horizonte, v. 1, n. 1, p. 139-146, 2005.

MAGALHÃES, F. M.; LARANJEIRAS, D. O.; COSTA, T. B.; JUNCÁ, F. A.; MESQUITA, D. O.; ROHR, D. L.; SILVA, W. P.; VIEIRA, G. H. C.; GARDA, A. A. Herpetofauna of protected areas in the Caatinga IV: Chapada Diamantina National Park, Bahia, Brazil. Herpetology Notes, Pisa, v. 8, p. 243-261, 2015.

MAGURRAN, A. E. Measuring biological diversity. Oxford: Blackwell Science, 2004. 577 p.

MARQUES, R.; TINÔCO, M. S.; COUTO-FERREIRA, D.; FAZOLATO, C. P.; BROWNE-RIBEIRO, H.; TRAVASSOS, M. L. O.; DIAS, M. A.; MOTA, J. V. L. Reserva Imbassaí Restinga: inventory of snakes on the northern coast of Bahia, Brazil. Journal of Threatened Taxa, New Delhi, v. 3, n. 11, p. 2184-2191, 2011.

MELO, T. S.; MOTA, J. V. L.; PERES, M. C. L.; COELHO, H. E. A.; RIBEIRO, H. C. B. Distribution extension of Solifugids (Arachnida: Solifugae) to Atlantic Forest of Brazil. Check List, Rio Claro, v. 10, n. 1, p. 237-238, 2014.

MENEZES, C. M.; TINÔCO, M. S.; TAVARES, M. H.; BROWNERIBEIRO, H. C.; SILVA, V. S. A.; CARVALHO, P. A. Implantação, manejo e monitoramento de um corredor ecológico na restinga no litoral norte da Bahia. Revista Brasileira de Biociências, Porto Alegre, v. 5, p. 201-203, 2007.

MESQUiTA, D. O.; COSTA, G. C.; GARDA, A. A.; DELFIM, F. R. Species composition, biogeography and conservation of the caatinga lizards. In: SILVA, J. M. C.; LEAL, I. R.; TABARELLI, M. (Ed.). Caatinga: the largest tropical dry forest region in South America. 1 ed. New York: Springer, 2017. p. 151-180.

MMA-MINISTÉRIO DO MEIO AMBIENTE. Áreas prioritárias para conservação, uso sustentável e repartição dos benefícios da biodiversidade brasileira: Caatinga. Brasília: Secretaria de Biodiversidade e Florestas, 2007. 301 p.

MMA - MINISTÉRIO DO MEIO AMBIENTE. $2^{\text {a }}$ atualização das áreas e ações prioritárias para conservação, uso sustentável e repartição dos benefícios da biodiversidade. Brasília: Secretaria de Biodiversidade e Florestas, 2016. 
MMA - MINISTÉRIO DO MEIO AMBIENTE. Livro vermelho da fauna brasileira ameaçada de extinção. Brasília: ICMBio, $2018.495 \mathrm{p}$.

MOTA, J. V. L.; CARVALHO, A. A. F.; TINÔCO, M. S. Composição da avifauna e sua relação com áreas manejadas na restinga da Reserva Imbassaí, Litoral Norte da Bahia, Brasil. Ornithologia, Cabedelo, v. 5, n. 1, p. 6-18, 2012.

PEDROSA, I. M. M. C.; COSTA, T. B.; FARIA, R. G.; FRANÇA, F. G. R.; LARANJEIRAS, D. O.; PEREIRA, T. C. S. O.; PALMEIRA, C. N. S.; TORQUATO, S.; MOTT, T.; VIEIRA, G. H. C.; GARDA, A. A. Herpetofauna of protected areas in the Caatinga III: the Catimbau National Park, Pernambuco, Brazil. Biota Neotropica, Campinas, v. 14, n. 4, p. 1-12, 2014.

PRADO, D. E. As caatingas da América do Sul. In: LEAL, I. R.; TABARELLI, M.; SILVA, J. M. C. (Ed.). Ecologia e conservação da Caatinga. 1 ed. Recife: Ed. Universitária da UFPE, 2003. p. 3-73.

QUEIROZ, L. P.; CARDOSO, D.; FERNANDES, M. F.; MORO, M. F. Diversity and evolution of flowering plants of the Caatinga domain. In: SILVA, J. M. C.; LEAL, I. R.; TABARELLI, M. (Ed.). Caatinga: the largest tropical dry forest region in South America. 1 ed. New York: Springer, 2017. p. 23-64.

RODRIGUES, M. T. Herpetofauna da Caatinga. In: LEAL, I. R.; TABARELLI, M.; SILVA, J. M. C. (Ed.). Ecologia e Conservação da Caatinga. 1 ed. Recife: Ed. Universitária da UFPE, 2003. p. 181-236.
SILVA, J. M. C.; BARBOSA, L. C. F. Impact of human activities on the caatinga. In: SILVA, J. M. C.; LEAL, I. R.; TABARELLI, M. (Ed.). Caatinga: the largest tropical dry forest region in South America. 1 ed. New York: Springer, 2017. p. 3-22.

SILVA, J. M. C.; BARBOSA, L. C. F.; LEAL, I. R.; TABARELLU, M. The Caatinga: Understanding the Challenges. In: SILVA, J. M. C.; LEAL, I. R.; TABARELLI, M. (Ed.). Caatinga: the largest tropical dry forest region in South America. 1. ed. New York: Springer, 2017. p. 359-368.

SILVA, J. M. C.; TABARELLI, M.; FONSECA, M. T.; LINS, L. V. Biodiversidade da Caatinga: áreas e ações prioritárias para a conservação. Brasília: Ministério do Meio Ambiente, 2004. 382 p.

TABARELLI, M.; SILVA, J. M. C. Áreas e ações prioritárias para a conservação da biodiversidade da Caatinga. In: LEAL I. R.; TABARELLI, M.; SILVA, J. M. C. (Ed.). Ecologia e Conservação da Caatinga. 1. ed. Recife: Ed. Universitária da UFPE, 2003. p. 777-796.

TABARELLI, M.; VICENTE, A. Lacunas de conhecimento sobre as plantas lenhosas da caatinga. In: SAMPAIO, E. V. S. B.; GIULIETTI, A. M.; VIRGÍLIO, J.; GAMARRA-ROJAS, C. (Ed.). Vegetação e flora da Caatinga. Recife: Associação de Plantas do Nordeste e Centro Nordestino de Informações sobre Plantas, 2002. p. 25-40. 